\title{
講演 2
}

\section{肺がん検診の基本的な考え方と最近の動向}

\section{原田眞雄}

索引用語——肺がん検診, 低線量 $\mathrm{CT}$ 検診

\section{はじめに}

免疫療法が肺癌診療を席巻している昨今, 患者及び社 会全体の利益やコストを考えるなら，早期発見と救命を 目指す検診の役割は改めて重要であると言えよう。米国 の大規模な無作為化比較試験の結果が 2011 年に公表さ れた後, しばらく大きな動きはなかったが, 一昨年以降, 低線量 $\mathrm{CT}$ 検診の有効性を証明あるいは示唆する研究報 告が相次いだ。本稿では検診の基本を確認した上で現行 検診及び低線量 CT 検診の最近の動向について概説す る.

\section{1. がん検診の基本的な考え方}

がん検診の目標はがん死亡率の減少であり，そのため には正しい（死亡減少効果の科学的根拠のある）検診を 広く（高い受診率で）正しく（高い精度で適切に）行う 必要がある。

\section{1. がん検診の有効性評価}

検診で発見される肺癌の生存率は自覚症状で発見され る肺癌に比べてはるかに良好であるが，それで死亡減少 効果が証明されたことにはならない。生存率などの発見 癌に限った指標には検診効果の過大評価につながる以下 のバイアスが存在するからである。それは，1レングス バイアス（進行が速く予後の悪い癌ほど検診の合間に自 覚症状で発見されやすい)，(2)過剩診断バイアス(進行が 極めて遅く検診でしか見つからない所謂がんもどきは発 見率や生存率をかさ上げするが死亡減少には寄与しな い)，(3)ルフセレクションバイアス(検診受診者は一般 に健康意識が高く生活習慣に留意しているので癌の罹患
率及び死亡率がそもそも低い）である。したがって，発 見癌という限られた集団ではなく，検診間発見癌を含む 検診受診者全体の癌死亡率を有効性評価の指標としなけ ればならない。

検診の有効性を評価する研究方法には，無作為化比較 試験, コホート研究, 症例対照研究がある。最も信頼性 の高い無作為化比較試験は，大規模かつ長期の観察を必 要とするので実施が容易でなく, また, コンプライアン スやコンタミネーションに十分留意する必要がある。他 の 2 つ方法はセルフセレクションバイアスの制御が問 題となる.

検診はその国の保健・医療システムと密接に関連する ため, 研究結果が他の国にも同じく通用するとは限らな い. 有効の判断を下すには陽性研究が複数はあってほし い.

\section{2. がん検診の精度管理}

検診は, スクリーニング〜精検〜精査〜治療, さらに は，対象者の把握〜受診勧奨〜多岐にわたる受診後の追 跡などから成るシステムである，各部分の精度を全て高 く保ち適切に運用しなければ，研究で観察された死亡減 少効果を現場で再現することはできない，そのために各 検診機関・実施主体の市区町村・それを束ねる都道府県 は，それぞれの立場で実態の把握と分析を行い精度の維 持向上に努める必要がある。

検診受診者は有病率の低い無症状の健常者であるから 検診に伴う不利益は最小化しなければならない。不利益 には偽陽性・過剩診断・放射線被曝・検查治療の合併症 がある，偽陽性については要精検率を適正なレベルに抑 えること, CT 検診で問題となる過剰診断についてはす 
りガラス結節を安易に精査や手術に回さないことが求め られる。当然ながら CT 検診を非低線量で行ってはいけ ない.

検診は規定の間隔で繰り返し受診するのが鉄則であ る. 初回検診ではそれまでに蓄積された無症状だが手遅 れの進行癌を拾い上げるため効果は限られるが, 繰り返 し検診によって進行期に至る前に発見される癌が増え る, すなわち進行癌が減ることになり (ステージシフト), 死亡減少がもたらされる.

\section{2. 現行検診とその課題}

わが国における現行検診は, 年 1 回行う胸部 X 線と喀 痰細胞診の併用法である．前者は 2 人の医師による二重 読影及び過去画像との比較読影が行われる，後者は肺門 部癌の早期発見を目的とし対象は 50 歳以上の重喫煙者 に限られる。

\section{1. 現行検診の有効性評価}

1987 年に肺がん検診が老人保健事業として住民検診 に導入された後に有効性評価の機運が高まり, 厚生省の 班研究として 6 つの質の高い症例対照研究 1 が行われ た. その結果，いずれも $32 \%$ ～ $60 \%$ の死亡減少効果が示 され，うち 4 つは統計学的に有意であった. 加えて, 検 診の効果は 1 年しか続かないことや, 検診精度の高い地 域ほど効果が高いことも示された．現行検診についてわ が国のガイドラインは, 死亡減少の相応の証拠があり行 うことを勧める, と評価している。

\section{2. 欧米における有効性評価}

日本以外で現行検診の有効性を証明した研究は一つも ない. 1970 年代に欧米で行われた 4 つの無作為化比較試 験については試験自体の質, 診断精度や当時の医療水準 の低さなどが問題視されている.その後 1993 年に米国で 開始された PLCO (prostate, lung, colorectal, and ovarian）trial の肺がん検診部分 2 は, 2011 年に結果が公表さ れた際，日本で大きな反響を呼んだ。

この研究は，約 10\% の死亡減少を見込んで約 154,000 人を登録し, 検診群と対照群に無作為に割り付けて検診 群にのみ年 1 回, 計 3〜4回の胸部 X 線検査を提供, その 後 10〜11 年間追跡するというもので, 追跡終了時の肺癌 死亡相対危険度は 0.99 で有意差はなく検診は無効と結 論された。しかしながら，ここで問題になったのは観察 期間が長すぎることである。肺癌における「発見可能な 無症状期間」は平均 1〜 4 年とされており, 検診効果が最 も現れやすい時期は検診相終了後 5 年以内と推測され る. 実際, 検診相終了から $2 \sim 5$ 年後の相対危険度は 0.89〜0.93であり想定通りの効果が観察されている. し たがって, 無効というより約 10\% の死亡減少効果があっ たと解釈する方が妥当である.

\section{3. 現行検診の課題}

精度管理に関する課題は山積しているが，ここでは最 も身近な読影医の数と質の問題について触れたい. 本学 会のアンケート調査 3 では, われわれの予想通り読影医 の高齢化・非専門診療科医師の多さ・読影医の確保困難 などの実態が確認された。このような現状では認定制度 を含め読影医の要件を厳格化することは難しい. 本学会 では, 読影精度の維持向上を図るための次善の策として, さらに若い読影医のリクルートにもつながることを期待 して, 昨年度から学術集会において検診読影セミナーを 開催するとともに，今春学会ホームページ上に公開した 「肺がん検診のための胸部 X 線読影演習システム」を活 用する方向で検討を行っている.

\section{3. 低線量 CT 検診の動向}

低線量 CT 検診は 1993 年にわが国で始められた. 世界 をリードする観察研究が盛んに行われ，当初から高い発 見率・I 期率・生存率が報告される中, 主に任意型検診 として広く普及するに至った。 日本 CT 検診学会がガイ ドラインを作成し認定制度を実施するなど精度管理に取 り組んでいる.

\section{1. 欧米の無作為化比較試験}

2000 年代の複数の研究報告では死亡減少効果は示さ れなかった. 初めて低線量 CT 検診の有効性を証明した のは, 2011 年に結果が公表された米国の National Lung Screening Trial(NLST) 4-6 である. 約 53,000人の重喫煙 者を CT 群とX 線群に分けて両群に年 1 回の検診を 3 回提供し, その後約 5 年の追跡を行った結果, CT 群で $20 \%$ の有意な死亡減少を認めた. サブグループ別の死亡 減少効果は女性 $27 \%$, 腺癌 $25 \%$ に対し男性 $8 \%$, 扁平上 皮癌-23\%, 小細胞癌 10\% であった. わが国で多くを占め る細気管支肺胞上皮癌は全体の 1 割と少数であったが, その 7 割が過剩診断と推定された。この結果から, 米国 では重契煙者を対象とする CT 検診に対して 2015 年に 公的医療保険が適用されるようになった。

その後に報告された欧州の 3 つの小規模な無作為化比 較試験 (DLCST, MILD, DANTE) では死亡減少が全く 認められず，混沌とした状況が続く中，ようやく2018 年の世界肺癌会議において, NLST に次いで規模の大き な欧州の NELSON 研究の結果概要が報告された（未論 文化). 男性が $84 \%$ を占める約 15,000 人の中〜重喫煙者 を CT 群と無検診群に分け, CT 群に 5.5 年間で 4 回の検 診を提供し, その後 10 年追跡した結果, 男性で $26 \%$ の 有意な死亡減少が認められた. 女性は $61 \%$ の死亡減少で あった。

さらに一昨年と今年, 欧州の 3 つの小規模な無作為化 比較試験 (ITALUNG・MILD・LUSI) の長期追跡結果が 
報告され, $26 \%$ ３9\% の死亡減少が示された.このうち, LUSI 研究7 の女性サブグループ及び MILD 研究 8 におけ る死亡減少効果は統計学的に有意であった.

欧米の大規模な 2 つ試験が有効性を示し,さらに小 規模の試験も後に続いたことで高危険群に対する効果は ほほ確立したと言ってよい. 欧州では高危険群を対象と する低線量 CT 検診の実現に向けた取り組みが今後進め られていくだろう。一方, 低危険群については, 罹患率 が低い上に過剩診断が危惧されるため行うべきではない というのが欧米の考え方である.

\section{2. わが国における有効性評価}

有効性評価研究では欧米に後れを取ったわが国であっ たが, 厚労省班研究のコホート研究, 日立市における地 域相関・時系列研究 9 , 今年報告された日立市のコホート 研究10では, いずれも X 線群に比べて死亡減少を示唆す る結果が得られた。 しかも相対危険度は非契煙者の方が 低く, 非契煙者でより効果が高い可能性が示唆された. 非喫煙者肺癌は, アジアでは罹患率が欧米よりもはるか に高く無視できない患者群である，また，進行が遅く数 年に 1 回の受診で良いとされるため不利益の懸念も少な くなる．これらのことを考え合わせると，わが国で喫煙 者高危険群のみに対策型の CT 検診を行うのは恐らく難 しいだろう。

このような中, 非〜軽喫煙者に対して 5 年に 1 度の $\mathrm{CT}$ 検診が有効かどうかを検証する無作為化比較試験 (JECS 研究) が AMED 佐川班で進められている. 低危険 群を対象とした試験は日本でしか行えないものであり， 速やかな進捗を期待したい.

\section{終わりに}

高危険群に対する低線量 CT 検診の有効性はほほ確立 されたが, 低危険群についてはJECS 研究の進捗を見守 る他はない．その結果が判明するまで対策型検診への導 入は見送られる可能性が高いと思われるが, 実際に導入 されたとして, 読影医の確保が問題となる中, X 線写真 の 10 倍以上に増える読影量にどのように対応するのか, 読影体制一つを取っても難題が待ち受けている.
本論文内容に関連する著者の利益相反：なし

\section{REFERENCES}

1. Sagawa M, Nakayama T, Tsukada H, Nishii K, Baba T, Kurita Y, et al. The efficacy of lung cancer screening conducted in 1990s: four case-control studies in Japan. Lung Cancer. 2003;41:29-36.

2. Oken MM, Hocking WG, Kvale PA, Andriole GL, Buys SS, Church TR, et al. Screening by chest radiograph and lung cancer mortality: the Prostate, Lung, Colorectal, and Ovarian (PLCO) randomized trial. JAMA. 2011;306: 1865-1873.

3. 三友英紀, 中山富雄, 芦澤和人, 遠藤千顕, 小林 健, 佐 藤雅美, 他. アンケートによる検診胸部 X 線写真読影体 制の全国実態調查. 肺癌. 2018;58:243-251.

4. National Lung Screening Trial Research Team, Aberle DR, Adams AM, Berg CD, Black WC, Clapp JD, et al. Reduced lung-cancer mortality with low-dose computed tomographic screening. N Engl J Med. 2011;365:395-409.

5. Pinsky PF, Church TR, Izmirlian G, Kramer BS. The National Lung Screening Trial: Results stratified by demographics, smoking history, and lung cancer histology. Cancer. 2013;119:3976-3983.

6. Patz EF Jr, Pinsky P, Gatsonis C, Sicks JD, Kramer BS, Tammemägi MC, et al. Overdiagnosis in low-dose computed tomography screening for lung cancer. JAMA Intern Med. 2014;174:269-274.

7. Becker N, Motsch E, Trotter A, Heussel CP, Dienemann $\mathrm{H}$, Schnabel PA, et al. Lung cancer mortality reduction by LDCT screening- Results from the randomized German LUSI trial. Int J Cancer. 2019. doi: 10.1002/ijc.32486.

8. Pastorino U, Silva M, Sestini S, Sabia F, Boeri M, Cantarutti A, et al. Prolonged lung cancer screening reduced 10-year mortality in the MILD trial: new confirmation of lung cancer screening efficacy. Ann Oncol. 2019; 30:1162-1169.

9. Nawa T, Nakagawa T, Mizoue T, Kusano S, Chonan T, Hayashihara K, et al. A decrease in lung cancer mortality following the introduction of low-dose chest CT screening in Hitachi, Japan. Lung Cancer. 2012;78:225-228.

10. Nawa T, Fukui K, Nakayama T, Sagawa M, Nakagawa $\mathrm{T}$, Ichimura $\mathrm{H}$, et al. A population-based cohort study to evaluate the effectiveness of lung cancer screening using low-dose CT in Hitachi city, Japan. Jpn J Clin Oncol. 2019;49:130-136.

\section{Basics and Trends of Lung Cancer Screening}

Masao Harada 1

${ }^{1}$ Department of Respiratory Medicine, National Hospital Organization Hokkaido Cancer Center, Japan. 